\title{
Prevalence of metabolic syndrome in Iran: A meta-analysis
}

\author{
Rahim Ostovar ${ }^{1}$, Faezeh Kiani ${ }^{2}$, Fatemeh Sayehmiri ${ }^{3}$, Masood Yasemi ${ }^{4}$, Yazdan Mohsenzadeh ${ }^{5}$, Yousof \\ Mohsenzadeh $^{6}$
}

\begin{abstract}
${ }^{1} \mathrm{PhD}$, Associate Professor, Social Determinants of Health Research Center, Yasuj University of Medical Sciences, Yasuj, Iran

${ }^{2}$ Msc, Student Research Committee, Ilam University of Medical Sciences, Ilam, Iran

${ }^{3} \mathrm{PhD}$, Proteomics Research Center, Shahid Beheshti University of Medical Sciences, Tehran, Iran

${ }^{4}$ MD, Poostchi Ophthalmology Research Center, Shiraz University of Medical Sciences, Shiraz, Iran

${ }^{5}$ MSc, Department of Paramedical Sciences, Faculty of Emergency Medicine, Alborz University of Medical Sciences, Karaj, Iran

${ }^{6} \mathrm{MD}$, Assistant Professor, Department of Cardiology, School of Medicine, Ilam University of Medical Sciences, Ilam, Iran
\end{abstract}

Type of article: Meta-analysis

\begin{abstract}
Background: Metabolic syndrome) MetS( is a complex risk factor which increases the risk of cardiovascular diseases and type 2 diabetes. There are many studies with various populations and results about the prevalence of MetS in Iran; in order to authenticate these studies and have an overall estimation of its prevalence in Iran, performing a meta-analysis seems to be necessary.

Objective: This study aimed to investigate the prevalence of MetS and its components in Iran via meta-analysis method.

Methods: All associated published papers in national and international journals of PubMed, Scopus, Web of Science, Magiran, Iranmedex, Science Direct, Medlib, and SID databases were searched from January, 2000 to October, 2016. All types of studies, including local and national surveys that reported the prevalence of MetS among healthy populations in Iran were reviewed. The effects of age, sample size and publication date as possible sources of heterogeneity among the study findings was examined by meta-regression. P-values less than 0.05 were considered as significant in heterogeneity tests. All analysis was done by R Ver. 3.2.1 and STATA (version 10).

Results: Seventy eligible studies were selected for meta-analysis. The overall estimation of MetS prevalence was 25\% (95\% CI: 22-29\%) based on the Adult Treatment Panel III (ATP III) criteria, 30\% (95\% CI: 25-36\%) according to the International Diabetes Federation (IDF), and 39\% (95\% CI: 26-52\%) based on the Joint Interim Societies (JIS) criteria. The prevalence of MetS was lower in men than in women (26.9\% versus $35.7 \%)$. The prevalence of various MetS components including High TG (triglyceride), Low HDL-C, High BP and High FBS (fasting blood sugar) was $43 \%, 54 \%, 38 \%$ and $22 \%$ among the adult population.

Conclusion: Findings from the present meta-analyses study displayed a high prevalence of metabolic syndrome in Iran, especially in women, which increases with age in both sexes. It alerts health care providers and policy makers to find solutions in order to take action to reduce MetS risk in society.
\end{abstract}

Keywords: Prevalence, Dysmetabolic syndrome, Components, Population groups, Meta-analysis, Iran

\section{Introduction}

Metabolic Syndrome (MetS), known also as Met Syn or Syndrome X, is a complex metabolic disorder which was at first introduced by Hanefeld and Leonhardt and later defined by Dr. Reaven from Stanford University $(1,2)$. This syndrome includes obesity, dyslipidemia (low HDL-c and hypertriglyceridemia), hypertension and impaired glucose

\section{Corresponding author:}

Assistant Professor Dr. Yousof Mohsenzadeh, Department of Cardiology, School of Medicine, Ilam University of Medical Sciences, Ilam, Iran. Tel: +98.8433347643, Fax: +98.8433347643, Email: y.mohsenzadeh@yahoo.com Received: December 20, 2016, Accepted: June, 02, 2017, Published: October 2017 iThenticate screening: May 15, 2017, English editing: September 20, 2017, Quality control: October 03, 2017 (C) 2017 The Authors. This is an open access article under the terms of the Creative Commons Attribution-NonCommercialNoDerivs License, which permits use and distribution in any medium, provided the original work is properly cited, the use is non-commercial and no modifications or adaptations are made. 
tolerance, which any three of these criteria constitute diagnosis of MetS and its simultaneous occurrence is more probable than each one per se (1-3). As insulin resistance is an underlying cause of the other risk factors, especially type 2 diabetes and CVD, MetS is also called "insulin resistance syndrome" (4). There are several definitions for MetS; the most commonly used definitions for MetS are those provided by the World Health Organization (WHO), the National Cholesterol Education Program-Adult Treatment Panel III (NCEP-ATP III), the International Diabetes Federation (IDF), and the Joint Interim Societies (JIS) (5). Although there are a number of different definitions for MES by various health organizations, the basic components remain constant and include hypertension (HTN), abdominal obesity, glucose intolerance or diabetes, and atherogenic dyslipidemia (6). MetS has deleterious effects and its component increase the chance of cardiovascular diseases (CVD), diabetes, and all-cause mortality (3-6). CVD mortality is significantly higher in MetS patients $(7,8)$. Because of the relationship between this syndrome, diabetes, and CVD and its high prevalence, MetS has been considered by most researchers (7-9). The Framingham study showed that MetS alone is a predictor of nearly $25 \%$ of CVD new cases (3). In the last two decades, CVD mortality has increased 20 to $45 \%$ which one of its underlying reasons was MetS (10) so that it increases total mortality from cardiovascular disease by 1.5 -fold and risk for cardiovascular death by 2.5 -fold (3,7-10). In addition, this syndrome increases the risk of diabetes mellitus 3 times (10). It seems that various factors, including ethnic predisposition, gender, age, race, cultural and lifestyle habits, stress, sedentary behavior, poor diet and socioeconomic status of a society's members affect the prevalence of MetS; thus, its prevalence has large variations in different societies (11-14). The incidence of chronic diseases and MetS in developing countries is more than in developed societies (15). One study in metropolitan Tehran, estimated that the MetS prevalence in the adult population was more than $30 \%$ (16). The nationwide prevalence of MetS in the adult population is reported to be $35.6 \%$ based on ATP III criteria, which is higher than in developed countries such as the United States $(17,18)$. Therefore, MetS is now an emerging health problem at public and individual levels. Strategies and programs for primary prevention of non-communicable diseases emphasize appropriate evaluation and management of risk factors (19), so determining the magnitude of MetS in various populations highlights the need for preventive and management strategies, and enables healthcare services planning. There are many different studies with various populations about the prevalence of MetS in Iran. So, it is very important to have an overall estimation of MetS prevalence by synthesizing available studies; also, understanding the breadth and quality of conducted studies is critical. Recently, one meta-analysis of 28 observational studies was conducted on this topic in Iran (5). Although this review estimated the prevalence of MetS in the adult population, the authors did not perform a meta-analysis among children and adolescents. It seems that CVD risk factors coexist in children similarly to adults. On the other hand, although atherosclerotic disorders are more prevalent in adults, it begins in younger ages (1). So MetS diagnosis among children and adolescents has a significant role in diabetes and CVD prevention (10). Thus we conducted a meta-analysis among children and adolescents. Also, in a recent meta-analysis, the prevalence of various components of the metabolic syndrome had not been definitively determined (5). Furthermore, since the publication of this meta-analysis, further studies have been published on this topic with clinically important results that have not yet been effectively summarized. In order to authenticate studies, performing an updated meta-analysis seems to be necessary. Thus, the main purpose of the present meta-analysis was providing an overall summary measure of prevalence rate of MetS and its components, in Iran.

\section{Material and Methods}

The present systematic review/meta-analysis which was performed in 2016-2017 sought to identify papers published on metabolic syndrome prevalence in Iran and included different parts such as problem definition, data collection, analysis, and interpretation of results.

\subsection{Search strategy}

We performed a literature search in English databases; PubMed/Medline, Scopus, and Web of Science from January, 2000 through October, 2016 using a number of keywords. Searching was done in a systematic way using keywords metabolic syndrome, dysmetabolic syndrome, cardiovascular syndrome, and insulin resistance syn-drome, prevalence and Iran,. The logical operator AND was used to combine the words together. All probable combinations of the Farsi equivalents of these words were searched for in these Persian databases: Iranmedex, Magiran, SID, and Irandoc. All related trials that were noted in the reference lists of each selected article were verified before inclusion. Bibliographies of retrieved articles were also searched for further references. Additionally, we also hand-searched non-published national surveys and references of selected citations as a further search tool. To decrease bias, two authors did search, selection of papers and extraction of data from articles, independently. In addition, when articles had incomplete data, at least three e-mails were sent to corresponding authors. 


\subsection{Inclusion and exclusion criteria}

All papers with the selected keywords in their titles or abstracts were included in the initial list, and other unrelated articles were eliminated. All types of studies, including local and national surveys that reported the prevalence of MetS in Iran were reviewed. We limited the final review to studies with random sampling on healthy children and adolescents who were under 18 years $(<18$ years) and/or healthy adults who were aged 18 years and over $(\geq 18$ years). Studies were excluded if they were conducted on subjects with known health disorders, if they did not provide data that allowed calculation of standard errors for effect estimates, if they were Meta-analyses and systematic reviews, or if they were a duplicate publication of another study. In cases of multiple publications from the same population or cohort, only the largest study was included. The STROBE (strengthening the reporting of observational studies in epidemiology) statement was used for quality control of the studies (20). Non-qualified studies were excluded. When necessary, authors were contacted for additional information. The flowchart of selection of article is illustrated in Figure 1.

562 studies were identified from different databases

Excluded:

Unrelated title and abstract $(\mathrm{n}=267)$

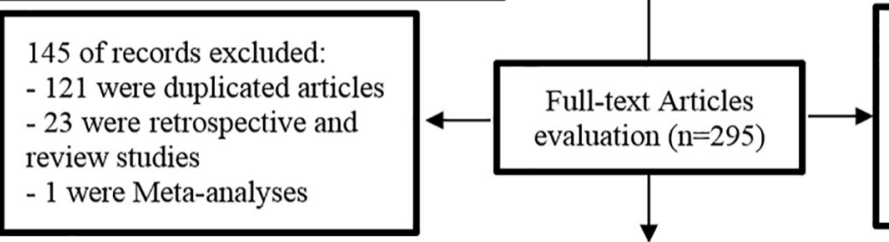

80 of records excluded:

-37 didn't have random sampling

-32 had the same target population

-11 were excluded Because of

overlapping publication

70 studies included in qualitative synthesis

(meta-analysis)

Figure 1. The flowchart of selected articles for final analysis

\subsection{Data extraction}

The following items were extracted from the studies: first author's name, study location, study date, publication date, definition used for MetS, sex groups, mean age, age range, sample size, reported prevalence of MetS extracted by sex (men, women, and total) and age (children and adolescents, adults, and total), reported prevalence of various MetS components [High Waist circumference (WC), High triglycerides (TG), Low high-density lipoprotein cholesterol (HDL-C), High blood pressure (BP), High fasting blood sugar (FBS)] according to ATPIII criteria extracted by sex (men, women, and total) and age (children and adolescents, adults, and total), and its $95 \%$ confidence interval (CI) concerning the prevalence of MetS components. The abstracts and full articles were independently reviewed by two authors, and data were extracted according to protocol. Any inconsistencies were resolved between researchers by mutual agreement. All data were then admitted into data collection form and entered into Microsoft Excel.

\subsection{Data synthesis and Statistical analysis}

The main objective of the study was to evaluate the prevalence of MetS and its various components; therefore, its variance was estimated by binominal distributions. Weighting averaging was used to combine prevalence rate in different studies. Each study was given a weight equal to its inverse variance. The heterogeneity between studies was assessed using a Chi-square-based Q test. Wherever the results of studies were heterogeneous, random effects models were used in the meta-analysis. Due to the significant heterogeneity of the studies, the random effects model was applied. The findings are described in forest plots (the point estimations and their $95 \% \mathrm{CI}$ ). The effects of age, sample size and publication date as possible sources of heterogeneity among the study findings was examined by meta-regression. Funnel plots and Egger test were used to examine publication bias. P-values less than 0.05 were considered as significant in heterogeneity tests. Sensitivity analyses were pre-specified. The analyses were conducted with R Software (version 3.2.1) and STATA (version 10).

\section{Results}

In the primary search, a list of 562 papers and abstracts yielded by searching, was considered relevant and screened. Of these studies, 267 papers were excluded based on title and abstract evaluation (Of these, 115 were on subjects 
with diseases, 152 were unrelated) and 295 articles were retained for detailed full-text evaluation. In the next step and after full-text evaluation, we excluded another 225 articles (Of these, 37 did not have random sampling, 121 were duplicated articles, 23 were retrospective and review studies, 1 was Meta- analysis , 43 were excluded because of the same target population and overlapping publication); Finally, 67 local studies and 3 national studies that were published between 2003 and 2016 (1, 4-6, 10, 15-17, 21-82) were identified for meta-analysis (Figure 1). The characteristics and extracted data from these studies are shown in Table 1.

Table 1. Characteristics of different investigated studies ( $T=$ total, $M=$ male, $F=$ female).

\begin{tabular}{|c|c|c|c|c|c|c|}
\hline $\begin{array}{l}\text { Ref. } \\
\text { no }\end{array}$ & Study year & Location & Gender & $\begin{array}{l}\text { Sample } \\
\text { Size }\end{array}$ & $\begin{array}{l}\text { Age group } \\
\text { (year) }\end{array}$ & $\begin{array}{l}\text { Age (year); } \\
\text { Mean } \pm \text { SD }\end{array}$ \\
\hline 16 & 2003 & Tehran & Both & 10,363 & $20 \leq$ & - \\
\hline 3 & 2006 & Yazd & Both & 1,110 & $20-74$ & $49 \pm 18$ \\
\hline 1 & 2006 & Tehran & Both & 1,067 & $3-9$ & $6.6 \pm 1.8$ \\
\hline 21 & 2006 & Tehran & Both & 515 & $7-11$ & - \\
\hline 22 & 2006 & Tehran & Both & 3,036 & $10-19$ & - \\
\hline 4 & 2006 & Tehran & Both & 1,480 & $25-64$ & $41.2 \pm 12.6$ \\
\hline 23 & 2006 & Isfehan, Irak, and Najaf-Abad & Both & 11,974 & $19 \leq$ & $35.6 \pm 3.4$ \\
\hline 24 & 2006 & Tehran & Both & 3,777 & $40 \leq$ & $53.7 \pm 9.9$ \\
\hline 25 & 2006 & Isfehan, Irak, and Najaf-Abad & Both & 12,600 & $20 \leq$ & - \\
\hline 26 & 2007 & Tehran & Both & 10,368 & $20 \leq$ & $42.7 \pm 15$ \\
\hline 27 & 2007 & Boshehr & Both & 3,723 & $25 \leq$ & - \\
\hline 15 & 2008 & Zanjan & Both & 507 & $17-21$ & - \\
\hline 28 & 2008 & Rafsanjan & Female & 1,221 & $14-18$ & $14.34 \pm 1.7$ \\
\hline 29 & 2008 & Tehran & Both & 4,568 & $20 \leq$ & $42.6 \pm 13.6$ \\
\hline 30 & 2008 & Esfahan & Both & 4,811 & $6-18$ & $12.7 \pm 3.2$ \\
\hline 31 & 2008 & Isfehan, Irak, and Najaf-Abad & Both & 12,514 & $19 \leq$ & - \\
\hline 10 & 2009 & Fars & Both & 1,402 & $18-90$ & $38.7 \pm 14.3$ \\
\hline 32 & 2009 & Mashhad & Female & 622 & $15-17$ & $16.4 \pm 0.9$ \\
\hline 33 & 2009 & Babol & Female & 944 & $30-50$ & $40.2 \pm 0.2$ \\
\hline 17 & 2009 & $\begin{array}{l}\text { All } 30 \text { provinces of Iran, } \\
\text { national study }\end{array}$ & Both & 2,966 & $25-64$ & $41.3 \pm 3.81$ \\
\hline 34 & 2009 & Esfahan & Female & 1,501 & $16-49$ & $38 \pm 8$ \\
\hline 35 & 2009 & Kashan & Male & 429 & $18 \leq$ & - \\
\hline \multirow[t]{3}{*}{36} & \multirow[t]{3}{*}{2009} & \multirow{3}{*}{ Zanjan } & \multirow[t]{3}{*}{ Both } & 2,941 & \multirow[t]{3}{*}{$20 \leq$} & \multirow[t]{3}{*}{-} \\
\hline & & & & 1,396 & & \\
\hline & & & & 1,545 & & \\
\hline \multirow[t]{3}{*}{37} & \multirow[t]{3}{*}{2010} & \multirow[t]{3}{*}{ Tehran } & \multirow[t]{3}{*}{ Both } & 1,523 & \multirow[t]{3}{*}{$10-19$} & \multirow[t]{3}{*}{$14.8 \pm 2.8$} \\
\hline & & & & 708 & & \\
\hline & & & & 815 & & \\
\hline 38 & 2010 & Tehran & Both & 137 & $60-90$ & - \\
\hline 39 & 2011 & Tehran & Female & 486 & $40-60$ & $49 \pm 6$ \\
\hline 40 & 2011 & $\begin{array}{l}\text { All } 30 \text { provinces of Iran, } \\
\text { national study }\end{array}$ & Both & 3,045 & $25-64$ & $43.59 \pm 11.2$ \\
\hline 41 & 2011 & Gorgan & Both & 450 & $15-17$ & $16 \pm 0.72$ \\
\hline 42 & 2011 & $\begin{array}{l}\text { All } 30 \text { provinces of Iran, } \\
\text { national study }\end{array}$ & Both & 8,733 & $25-64$ & - \\
\hline 43 & 2011 & Tabriz & Male & 76 & $18 \leq$ & $41.5 \pm 0.74$ \\
\hline 44 & 2011 & Jahrom & Both & 892 & $30 \leq$ & - \\
\hline 45 & 2011 & $\begin{array}{l}\text { Ghazvin, Kermanshah, } \\
\text { Golestan, and Hormozgan, } \\
\text { multicity study }\end{array}$ & Female & 914 & $18-45$ & - \\
\hline 46 & 2012 & Tehran & Both & 2,548 & $50 \leq$ & $60.3 \pm 7.4$ \\
\hline 47 & 2012 & Semnan & Both & 3,799 & $30-70$ & $45.8 \pm 10$ \\
\hline
\end{tabular}




\begin{tabular}{|c|c|c|c|c|c|c|}
\hline 6 & 2012 & Zahedan & Both & 1,802 & $19 \leq$ & $35.85 \pm 13.81$ \\
\hline 48 & 2012 & Gorga & Female & 100 & $40 \leq$ & $54.3 \pm 5.26$ \\
\hline 49 & 2012 & Babol & Both & 933 & $20 \leq$ & - \\
\hline 50 & 2012 & Kerman & Both & 711 & $15-75$ & $46.52 \pm 14.76$ \\
\hline 51 & 2012 & West Azerbaijan & Male & 12,138 & $20-69$ & - \\
\hline 52 & 2012 & Ghazvin & Male & 192 & $18 \leq$ & $39.4 \pm 1.3$ \\
\hline 53 & 2012 & Yazd & Both & 200 & $20-74$ & $48.75 \pm 15$ \\
\hline 54 & 2012 & Tehran & Both & 365 & $19 \leq$ & $45.7 \pm 16.2$ \\
\hline 55 & 2012 & Isfehan, Irak, and Najaf-Abad & Both & 6,323 & $35 \leq$ & $50.7 \pm 11.6$ \\
\hline 56 & 2012 & Greater Khorasan province & Both & 1,194 & $35-55$ & - \\
\hline 57 & 2012 & Bushehr Port & Female & 382 & $50-83$ & $58.78 \pm 7.8$ \\
\hline 58 & 2013 & Ahvaz & Both & 912 & $20 \leq$ & $42.27 \pm 14$ \\
\hline 59 & 2013 & Tehran & Both & 223 & $18-30$ & - \\
\hline 60 & 2013 & Arak & Both & 515 & $18 \leq$ & - \\
\hline 61 & 2013 & Gorgan & Female & 160 & $18 \leq$ & $32.33 \pm 7.08$ \\
\hline 62 & 2013 & Shiraz & Female & 434 & $40 \leq$ & $58.6 \pm 6.7$ \\
\hline 63 & 2013 & Tehran & Both & 46,665 & $20-70$ & $40.7 \pm 13.9$ \\
\hline 64 & 2013 & Qazvin & Both & 1,107 & $20-78$ & $40.8 \pm 10.33$ \\
\hline 65 & 2014 & Amol & Both & 5,826 & $16 \leq$ & $40.1 \pm 0.24$ \\
\hline 65 & 2014 & Zanjan & Both & 2,243 & $16 \leq$ & $36.5 \pm 0.39$ \\
\hline 66 & 2014 & Qazvin & Both & 996 & $24 \leq$ & $42.1 \pm 8.5$ \\
\hline 67 & 2014 & Ahvaz & Both & 2,246 & $10-19$ & - \\
\hline 68 & 2014 & Tehran & Both & 950 & $20 \leq$ & $46.5 \pm 14.4$ \\
\hline 69 & 2014 & Kerman & Both & 5,332 & $20 \leq$ & $46.1 \pm 5$ \\
\hline 70 & 2015 & Tehran & Both & 1,446 & $18-31$ & $14.6 \pm 2.2$ \\
\hline 71 & 2015 & Shiraz & Both & 377 & $20-86$ & $43.8 \pm 11$ \\
\hline 72 & 2015 & Qom & Both & 1,488 & $20 \leq$ & $36 \pm 7.7$ \\
\hline 73 & 2015 & Azerbaijan & Male & 10,000 & $20-74$ & $38.62 \pm 9.7$ \\
\hline 74 & 2015 & Lorestan & Both & 214 & $18-30$ & - \\
\hline 75 & 2015 & Birjand & Both & 1,425 & $6-11$ & 9.1 \\
\hline 76 & 2015 & Tehran & Both & 785 & $10-19$ & $14.8 \pm 2.9$ \\
\hline 77 & 2015 & Tehran & Female & 264 & $40 \leq$ & $53.98 \pm 5.57$ \\
\hline 78 & 2015 & Kerman & Both & 5,874 & $15-75$ & $44.34 \pm 16.32$ \\
\hline 79 & 2015 & Babolsar & Both & 134 & $18 \leq$ & $39.8 \pm 7.28$ \\
\hline 80 & 2016 & Shahroud & Both & 5,190 & $40-64$ & - \\
\hline 81 & 2016 & Shahroud & Male & 1,018 & $18 \leq$ & $42.17 \pm 10.65$ \\
\hline 82 & 2016 & Tehran & Male & 234 & $18 \leq$ & $36 \pm 10.3$ \\
\hline
\end{tabular}

The total sample sizes of studies using the criteria of ATP III, IDF and JIS were 145,887, 87,071, and 11,081, respectively. Among adults, the sample sizes were 128,464, 84,526, 9,635 and 3,770 based on ATP III, IDF, JIS and AHA definition. Also, the total sample sizes among children and adolescents were 17,423, 2,545, 1,446 and 1,300 using the ATP III, IDF, JIS and De Ferranti criteria (Table 2). Table 2 presents the pooled estimations MetS prevalence using meta-analysis of data extracted from population-based studies in Iran. Forty-two studies were included for the prevalence calculation based on ATPIII criteria; among these studies, we found 33 reports given according to ATP III among adults and nine reports among children and adolescents. Sixteen of the seventy studies estimated MetS prevalence based on IDF definition which was considered in the statistical analysis; of these studies, 13 reports were based on IDF among adults and three reports were among children and adolescents. Sex studies (five among adults and three among children and adolescents) had reported MetS prevalence based on JIS criteria. Among included studies, we found two reports given according to AHA definition among adults and one report given according to De Ferranti definition among children and adolescents. Among adults, the prevalence of MetS was $29.2 \%$ (95\% CI: $26.2-32.3 \%$ ) according to the ATP III, 32.8\% (95\% CI: $28.4-37.2 \%$ ) based on the IDF, $43.6 \%$ (95\% CI: 32.6- 54.5\%) for JIS, $34.5 \%$ (95\% CI: $17.8-51.1 \%$ ) according to the AHA definition and in total (31.6\% CI: 29.2-34.1\%). As it is shown, the prevalence of MetS measured by JIS has been higher than those measured by 
other definitions; however, there has been no statistically significant difference (Figure 2). Also, we estimated the prevalence of MetS in age groups $[\geq 18$ years of age] according to sex; the prevalence of MetS was lower in men than in women (24.1\% versus $35.4 \%$, respectively) for ATP III, (29.9\% versus $36.0 \%$, respectively) according to the IDF, (30.5\% versus $37.9 \%$, respectively) based on the AHA criteria and in total (26.9\% versus $35.7 \%$, respectively). However, the reverse was true for the JIS definition, which showed a significantly higher (15.2\%) prevalence in men than in women $(52.5 \%$ versus $37.3 \%$, respectively (Table 2$)$.

Table 2. The Overall Prevalence of Metabolic Syndrome in the Iranian Adult Population According to Different Criteria and Sex Using Random Effect Meta-Analysis of Data From Population-based Studies

\begin{tabular}{|c|c|c|c|c|c|}
\hline Criteria & Age group & Sample size & Prevalence (\%) & $\mathrm{I}^{2}(\%)$ & $\mathrm{p}$-value \\
\hline \multirow[t]{9}{*}{ ATP III } & \multirow[t]{3}{*}{ Adult } & \multirow[t]{3}{*}{128,464} & T: 29.2 & T: 99.3 & $\mathrm{~T}:<0.001$ \\
\hline & & & M: 24.1 & M: 98.9 & $\mathrm{M}:<0.001$ \\
\hline & & & F: 35.4 & F: 99.0 & $\mathrm{~F}:<0.001$ \\
\hline & \multirow[t]{3}{*}{ Children and adolescents } & \multirow[t]{3}{*}{17,423} & T: 9.8 & T: 96.8 & $\mathrm{~T}:<0.001$ \\
\hline & & & M: 11 & M: 92.6 & $\mathrm{M}:<0.001$ \\
\hline & & & F: 7.6 & F: 89.2 & $\mathrm{~F}:<0.001$ \\
\hline & \multirow[t]{3}{*}{ Total } & \multirow[t]{3}{*}{145,887} & T: 25 & T: 99.6 & $\mathrm{~T}:<0.001$ \\
\hline & & & M: 22 & M:98.9 & $\mathrm{M}:<0.001$ \\
\hline & & & F: 30 & F: 99.6 & $\mathrm{~F}:<0.001$ \\
\hline \multirow[t]{9}{*}{ IDF } & \multirow[t]{3}{*}{ Adult } & \multirow[t]{3}{*}{84,526} & $\mathrm{~T}: 32.8$ & T: 99.3 & $\mathrm{~T}:<0.001$ \\
\hline & & & M: 29.9 & M: 98.7 & $\mathrm{M}:<0.001$ \\
\hline & & & F: 36 & F: 99.2 & $\mathrm{~F}:<0.001$ \\
\hline & \multirow[t]{3}{*}{ Children and adolescents } & \multirow[t]{3}{*}{2,545} & $\mathrm{~T}: 5.5$ & $\mathrm{~T}: 0.00$ & $\mathrm{~T}:>0.001$ \\
\hline & & & M: 6.0 & M: 54.2 & $\mathrm{M}:>0.001$ \\
\hline & & & F: 3.9 & - & - \\
\hline & \multirow[t]{3}{*}{ Total } & \multirow[t]{3}{*}{87,071} & $\mathrm{~T}: 30$ & T: 99.6 & $\mathrm{~T}:<0.001$ \\
\hline & & & M: 26 & M: 99.2 & $\mathrm{M}:<0.001$ \\
\hline & & & F: 29 & F: 99.6 & $\mathrm{~F}:<0.001$ \\
\hline \multirow[t]{9}{*}{ JIS } & \multirow[t]{3}{*}{ Adult } & \multirow[t]{3}{*}{9,635} & $\mathrm{~T}: 43.6$ & T: 99.1 & $\mathrm{~T}:<0.001$ \\
\hline & & & M: 52.5 & & \\
\hline & & & F: 37.3 & F: 99.9 & $\mathrm{~F}:<0.001$ \\
\hline & \multirow[t]{3}{*}{ Children and adolescents } & \multirow[t]{3}{*}{1,446} & $\mathrm{~T}: 15$ & T: 0.00 & $\mathrm{~T}: 0.00$ \\
\hline & & & M: 30 & - & - \\
\hline & & & $F: 2.0$ & - & - \\
\hline & \multirow[t]{3}{*}{ Total } & \multirow[t]{3}{*}{11,081} & T: 39 & $\mathrm{~T}: 99.5$ & $\mathrm{~T}:<0.001$ \\
\hline & & & M: 41 & M: 97.9 & $\mathrm{M}:<0.001$ \\
\hline & & & $\mathrm{F}: 23$ & F: 99.8 & $\mathrm{~F}:<0.001$ \\
\hline \multirow[t]{5}{*}{ AHA } & \multirow[t]{3}{*}{ Adult } & \multirow[t]{3}{*}{3,770} & $\mathrm{~T}: 34.5$ & T: 98.7 & $\mathrm{~T}:<0.001$ \\
\hline & & & M: 30.5 & M: 93.0 & $\mathrm{M}:<0.001$ \\
\hline & & & F: 37.9 & F: 98.1 & $\mathrm{~F}:<0.001$ \\
\hline & Children and adolescents & - & - & - & - \\
\hline & Total & - & - & - & - \\
\hline \multirow[t]{5}{*}{ De Ferranti } & Adult & - & - & - & - \\
\hline & \multirow[t]{3}{*}{ Children and adolescents } & \multirow[t]{3}{*}{1,300} & $\mathrm{~T}: 17.5$ & T: 96.8 & $\mathrm{~T}:<0.001$ \\
\hline & & & M: 19 & M: 92.0 & $\mathrm{M}:<0.001$ \\
\hline & & & $F: 15.5$ & F: 90.5 & $\mathrm{~F}:>0.001$ \\
\hline & Total & - & - & - & - \\
\hline
\end{tabular}




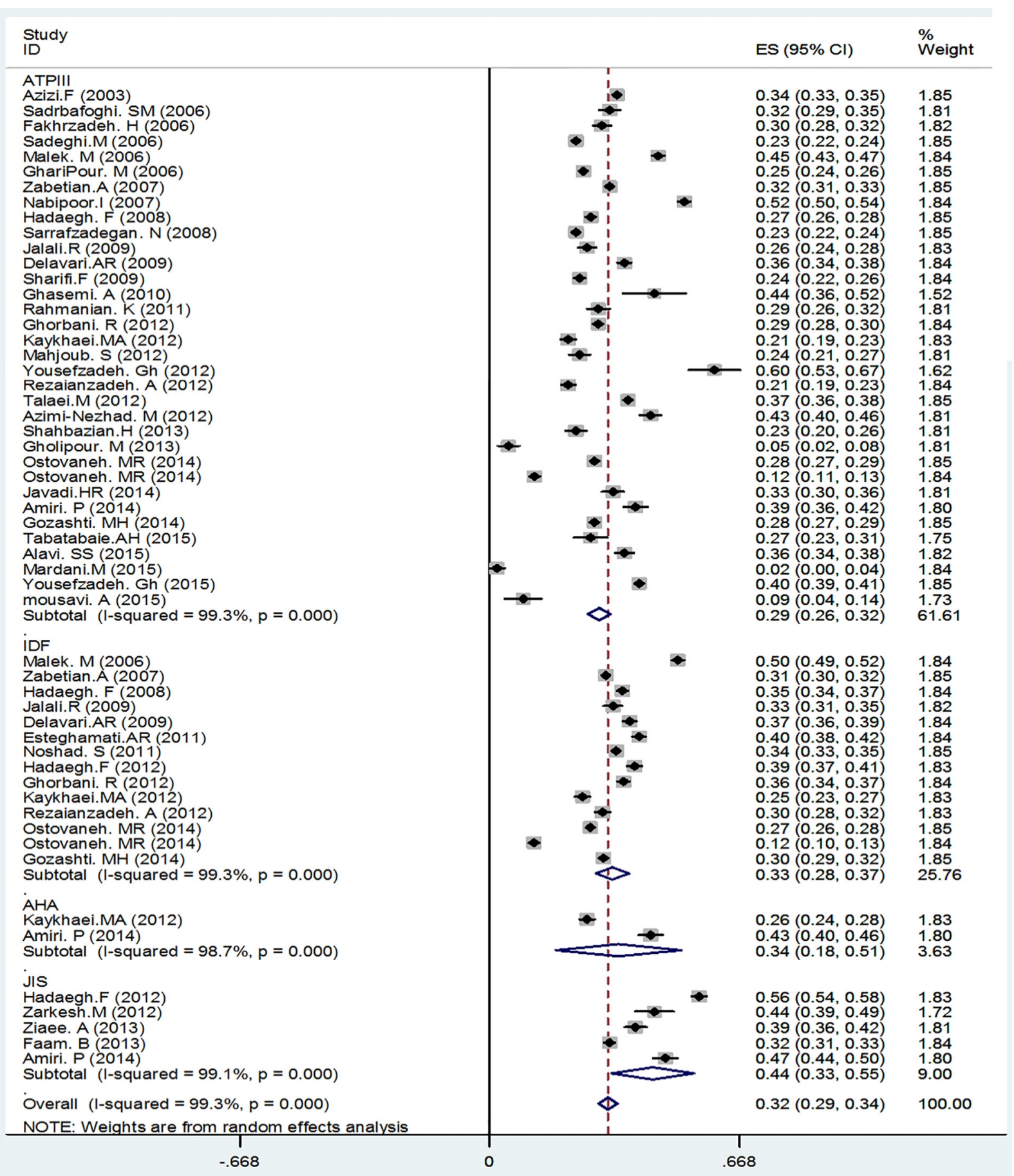

Figure 2. Forest plot of the Prevalence of Metabolic Syndrome in the Iranian Adult Population and its 95\% confidence interval, midpoint of each line segment represents the estimated prevalence in the study. Rhombic mark shows the prevalence in Iran extracted from all studies.

Among children and adolescents, the overall estimation of MetS was 9.8\% (95\% CI: 7.2- 12.5\%) according to the ATP III, 5.5\% (95\% CI: 4.6- 6.3\%) based on the IDF, 15\% (95\% CI: $13.2-16.8 \%)$ for JIS and $17.5 \%$ (95\% CI: $8.7-$ $26.3 \%$ ) according to the De Ferranti definition and in total (10.2\% CI: 8.0-12.5\%) (Figure 3). As it is shown in Figure 3, the prevalence of MetS measured by various criteria has been different; however, this difference was not statistically significant (Figure 3). Also, the prevalence of MetS was greater in boys than in girls $(11 \%$ versus $7.6 \%$, respectively) based on the ATP III (6.0\% versus $3.9 \%$, respectively) for IDF, (30.0\% versus $2.0 \%$, respectively) 
according to the JIS, (19.0\% versus $15.5 \%$, respectively) based on the De Ferranti criteria and in total (13.0\% versus $7.4 \%$, respectively) (Table 2). Table 3 shows the pooled estimations of prevalence of various components of the metabolic syndrome according to ATPIII criteria using random effect meta-analysis of data extracted from population-based studies in Iran. Metabolic syndrome components prevalence in age groups [ $\geq 18$ years of age] was as follows: High WC (Waist Circumference) $41 \%$ (95\% CI: 32-50\%), High TG (triglyceride) $43 \%$ (95\% CI: 38 49\%), Low HDL-C (High-density lipoprotein-Cholesterol) 54\% (95\% CI: 48-61\%), High BP (Blood Pressure) 38\% (95\% CI: 31-44\%) and High FBS (Fasting Blood Sugar) 22\% (95\% CI: 17-26\%). The overall estimations of prevalence of various MetS components in age [ $<18$ years of age] were as follows: High WC $12 \%$ (95\% CI: 7.0 17\%), High TG 34\% (95\% CI: 19-48\%), Low HDL-C 31\% (95\% CI: 10-52\%), High BP 17\% (95\% CI: 10-24\%) and High FBS 9\% (95\% CI: 6-12\%). Having a WC higher than the normal value was more common for adult women than men (59\% versus $27 \%$, respectively); whereas among children and adolescents, the frequency of High WC was almost equal in both sexes (11\% versus $9 \%$, respectively). Similar changes were also apparent for HDL-C level lower than the normal value; while among the adult population, the prevalence of low HDL-C was much higher in women than in men ( $60 \%$ versus $48 \%$, respectively), among children and adolescents, the rate was almost similar in boys and girls ( $23 \%$ versus $30 \%$, respectively). Among the adult population, hypertriglyceridemia was more prevalent in men than in women ( $49 \%$ versus $41 \%$, respectively); however, this difference was not statistically significant. Having a TG higher than the normal value was almost similar in both sexes among children and adolescents (32\% versus $34 \%$, respectively).

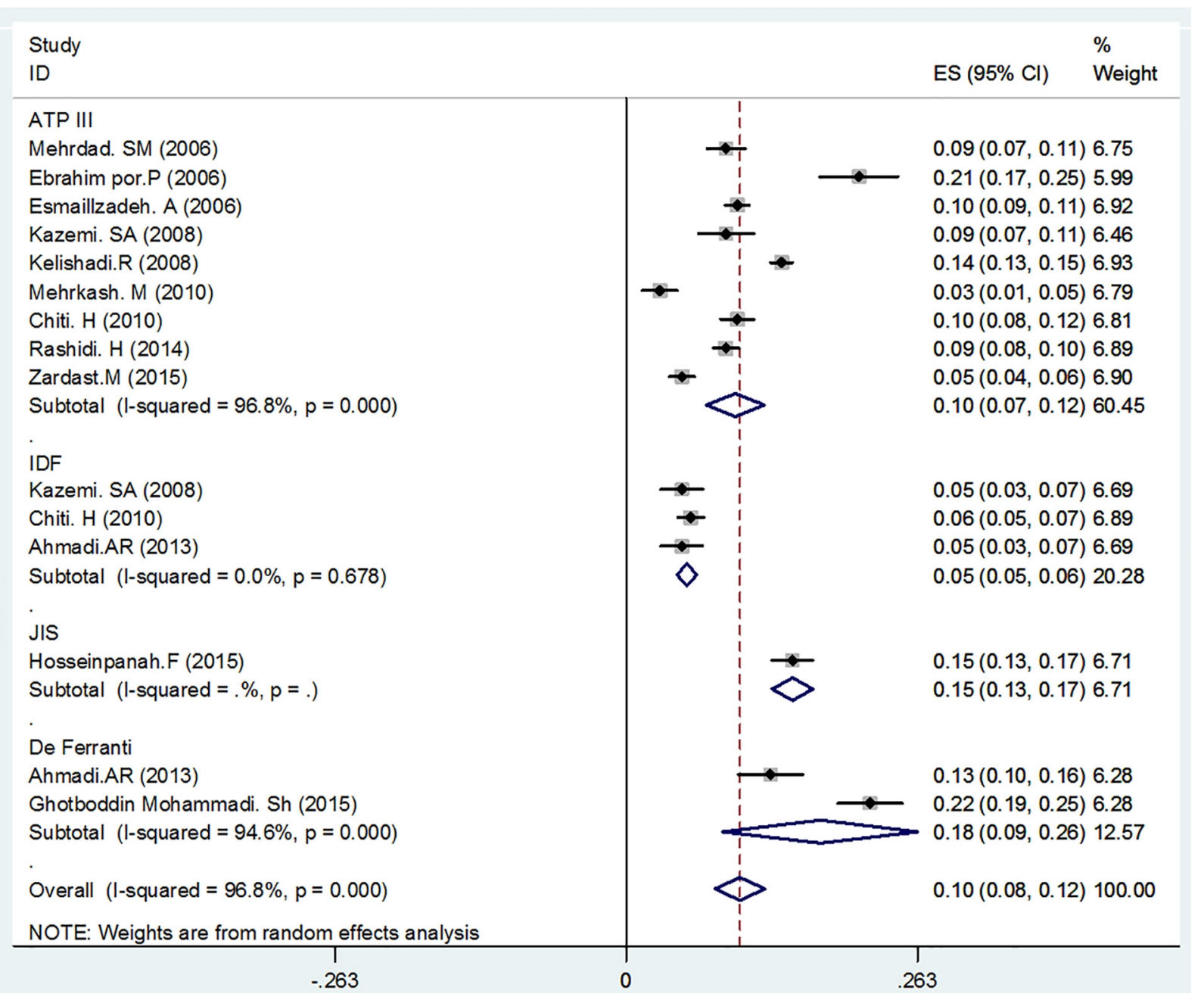

Figure 3. Forest plot of the Prevalence of Metabolic Syndrome in the Iranian children and adolescents and its 95\% confidence interval, midpoint of each line segment represents the estimated prevalence in the study. Rhombic mark shows the prevalence in Iran extracted from all studies 
http://www.ephysician.ir

Table 3. Prevalence of various components of the metabolic syndrome (ATPIII criteria) in various age groups based on gender using random effect meta-analysis of data extracted from population-based studies in Iran

\begin{tabular}{|c|c|c|c|c|}
\hline Variable & & Prevalence (\%) & $\mathrm{I}^{2}(\%)$ & p-value \\
\hline \multirow[t]{9}{*}{ High WC } & \multirow[t]{3}{*}{ Adult } & $\mathrm{T}: 41$ & T: 99.9 & $<0.001$ \\
\hline & & M: 27 & M: 99.8 & $<0.001$ \\
\hline & & F: 59 & F: 99.7 & $<0.001$ \\
\hline & \multirow[t]{3}{*}{ Children and adolescents } & $\mathrm{T}: 12$ & T: 99.1 & $<0.001$ \\
\hline & & M: 11 & M: 97.9 & $<0.001$ \\
\hline & & F: 9 & F: 95.8 & $<0.001$ \\
\hline & \multirow[t]{3}{*}{ Total } & T: 34 & T: 99.9 & $<0.001$ \\
\hline & & M: 24 & M: 99.8 & $<0.001$ \\
\hline & & F: 47 & F: 99.9 & $<0.001$ \\
\hline \multirow[t]{9}{*}{ High TG } & \multirow[t]{3}{*}{ Adult } & $\mathrm{T}: 43$ & T: 99.7 & $<0.001$ \\
\hline & & M: 49 & M: 99.4 & $<0.001$ \\
\hline & & F: 41 & F: 99.0 & $<0.001$ \\
\hline & \multirow[t]{3}{*}{ Children and adolescents } & $\mathrm{T}: 34$ & T: 99.8 & $<0.001$ \\
\hline & & M: 32 & M: 99.5 & $<0.001$ \\
\hline & & $F: 34$ & F: 99.5 & $<0.001$ \\
\hline & \multirow[t]{3}{*}{ Total } & $\mathrm{T}: 47$ & T: 99.9 & $<0.001$ \\
\hline & & M: 45 & M: 99.6 & $<0.001$ \\
\hline & & F: 39 & F: 99.4 & $<0.001$ \\
\hline \multirow[t]{9}{*}{ Low HDL } & \multirow[t]{3}{*}{ Adult } & $\mathrm{T}: 54$ & T: 99.8 & $<0.001$ \\
\hline & & M: 48 & M: 99.8 & $<0.001$ \\
\hline & & $F: 60$ & F: 99.6 & $<0.001$ \\
\hline & \multirow[t]{3}{*}{ Children and adolescents } & $\mathrm{T}: 31$ & T: 99.9 & $<0.001$ \\
\hline & & M: 23 & M: 99.3 & $<0.001$ \\
\hline & & $F: 30$ & F: 99.8 & $<0.001$ \\
\hline & \multirow[t]{3}{*}{ Total } & $\mathrm{T}: 49$ & T: 99.9 & $<0.001$ \\
\hline & & M: 42 & M: 99.8 & $<0.001$ \\
\hline & & F: 52 & F: 99.8 & $<0.001$ \\
\hline \multirow[t]{9}{*}{ High BP } & \multirow[t]{3}{*}{ Adult } & $\mathrm{T}: 38$ & T: 99.8 & $<0.001$ \\
\hline & & M: 38 & M: 99.8 & $<0.001$ \\
\hline & & F: 31 & F: 99.6 & $<0.001$ \\
\hline & \multirow[t]{3}{*}{ Children and adolescents } & T: 17 & $\mathrm{~T}: 99.3$ & $<0.001$ \\
\hline & & M: 21 & M: 98.2 & $<0.001$ \\
\hline & & F: 16 & F: 98.5 & $<0.001$ \\
\hline & \multirow[t]{3}{*}{ Total } & $\mathrm{T}: 52$ & T: 99.8 & $<0.001$ \\
\hline & & M: 33 & M: 99.8 & $<0.001$ \\
\hline & & F: 34 & F: 99.8 & $<0.001$ \\
\hline \multirow[t]{9}{*}{ High FBS } & \multirow[t]{3}{*}{ Adult } & $\mathrm{T}: 22$ & T: 99.8 & $<0.001$ \\
\hline & & M: 26 & M: 99.8 & $<0.001$ \\
\hline & & F: 21 & F: 99.5 & $<0.001$ \\
\hline & \multirow[t]{3}{*}{ Children and adolescents } & T: 9.0 & T: 98.9 & $<0.001$ \\
\hline & & M: 12 & M: 98.5 & $<0.001$ \\
\hline & & F: 8.0 & F: 97.8 & $<0.001$ \\
\hline & \multirow[t]{3}{*}{ Total } & $\mathrm{T}: 28$ & T: 99.5 & $<0.001$ \\
\hline & & M: 23 & M: 99.8 & $<0.001$ \\
\hline & & F: 18 & F: 99.5 & $<0.001$ \\
\hline
\end{tabular}

The prevalence of abnormal FPG was much higher in men than in women (26\% versus $21 \%$, respectively) and in boys than girls ( $12 \%$ versus $8 \%$, respectively); however, there was no statistically significant difference by gender. The same trend was obtained for the prevalence of hypertension, which found High BP to be less prevalent in women than in men (31\% versus $38 \%$, respectively) and in boys than girls (16\% versus $21 \%$, respectively) (Table 3). Table 4 shows the meta-regression parameters. Interpretation of meta-regression showed that there was no 
significant relationship between the prevalence of metabolic syndrome and sample size $(p \geq 0.05)$; the reason could be related to a larger sample size with more MetS prevalence and vice versa. Figure 4 presents the Begg's funnel plot of the association between MetS prevalence and year of each published paper in Iran. Regression analysis of this plot indicated no significant asymmetry $(\mathrm{p} \geq 0.05)$ and thus no evidence of bias (Figure 4$)$. As the slope of metaregression line was negative $(\mathrm{p}=0.251)$, there was no association between the metabolic syndrome prevalence with year of study in Iran. The results of the meta-regression show that the main source of heterogeneity in findings was the mean age of participants. The metabolic syndrome prevalence in age groups [ $<18$ years of age] $10.2 \%$ (CI: 10.0 $19 \%$ ) and [ $\geq 18$ years of age] 31.6\% (CI 95\%: 29.2-34.1) was estimated. The results show that by each year increase in the mean age of individuals after the age of 18 , the prevalence of MetS increased by $0.004 \%$ (coefficient: $0.0048792, \mathrm{p}=0.005)$.

Table 4. Source of heterogeneity by multivariate meta-regression analysis

\begin{tabular}{|l|l|l|l|}
\hline Factors & Coefficient & Standard error & $P$ \\
\hline Published year & 5.465677 & 3.614012 & 0.136 \\
\hline Sample size & 1.305741 & 0.87 & 0.84 \\
\hline Mean age & 0.0048792 & 0.02156 & 0.005 \\
\hline
\end{tabular}

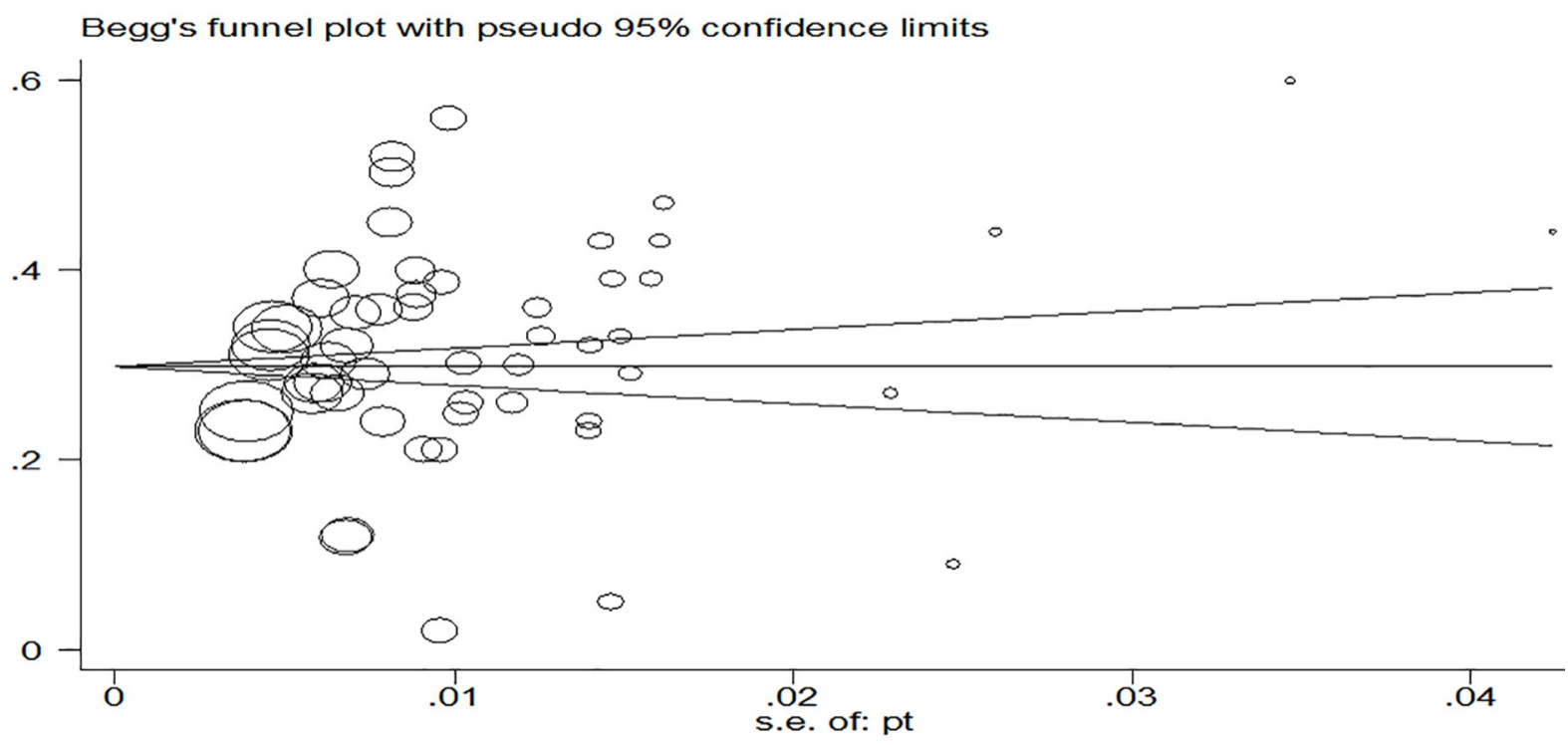

Figure 4. Begg's funnel plot for publication bias in the risk difference (RD) analysis.

\section{Discussion}

In the present study, we considered the prevalence of MetS and its components in our systematic search. We limited our analysis to two age groups: children and adolescents who were under 18 years $(<18$ years $)$ and/or adults who were aged 18 years and over $(\geq 18$ years). Our findings indicate that the prevalence of MetS for age groups $(<18$ years of age) was $10.2 \%$ (9.8\%: ATP III, 5.5\%: IDF, $15.0 \%$ : JIS, $17.5 \%$ : De Ferranti). The present study showed that the prevalence of MetS among children and adolescents in Iran was higher than in many other countries. In a study conducted in eight European countries among children MetS prevalence was 5.5\% (83) and in the U.S, the prevalence of MetS among children and adolescents has been reported as 3.1\% to $12.7 \%$ with different definitions (84). Prevalence rate of MetS among children and adolescents is very much dependent on the various definitions offered. This figure was $8.9 \%$ in 8 to 9-year-old Brazilian children by adopting specific criteria for age (85), $6.5 \%$ in Mexico using modified ATP III criteria (86), 6.3\% in 7-15-year-old children based on IDF criteria in Turkey (87), $4 \%$ based on the modified -ATPIII criteria in Tunisia (88), $6.6 \%$ using the De Ferranti definition among elementary school children of China (89), 4.2\% using modified ATPIII criteria in north India (90) and $16.5 \%$ to $18 \%$ among school-aged children in Pakistan based on various definitions (91). The absence of a comprehensive and universal definition of MetS in children and adolescents could, to some extent be a factor in the difference between the reported rates of prevalence from the numerous studies throughout the world. It has also been revealed through conducted studies that over time, the prevalence of MetS is increasing in these age groups. Furthermore, recent reports indicate that due to the increasing rate of childhood obesity on a global scale, the prevalence of childhood 
MetS has substantially increased during childhood and adolescence $(92,93)$. It appears that in developing countries including Iran, childhood obesity plays a major role in the high prevalence of pediatric MetS. Furthermore, obesity, particularly in the central (abdominal) region, is now being considered as a key factor in MetS (75). If the occurrence of MetS in children and adolescents is identified early, risk stratification of future cardiovascular events can be performed.

Another finding of this study indicates that the prevalence of MetS is relatively high in the Iranian adult population according to all definitions (31.6\% (29.2\%: ATP III, 32.8\%: IDF, 43.6\%: JIS and 34.5\%: AHA)). This was according to the population-based studies in different cities of Iran. In another meta-analysis in Iran, prevalence of MetS among adults with 28 eligible studies was 37\% (ATPIII: 36.9\%, IDF: $34.6 \%$, and JIS: $41.5 \%$ ) which was almost similar to our findings (5). So, the prevalence of MetS in Iran was expected to be high. These observed prevalence rates are noticeably higher than the estimated prevalence around the world, which is between $20 \%$ and $25 \%$ (94). A series of studies on the occurrence of the MetS in Europe have been reported to be $\leq 30 \%$, which is lower than the results of the present study (95). The corresponding figure for MetS prevalence was approximately $26.6 \%$ in Spain (96), 20\% in Italy (97), 27.6\% in Portugal (98) and $20.2 \%$ in France (99). It was also higher than in the United States (22.9\%) (100). Grundy reported that between $20 \%$ and $30 \%$ of the adult population in most countries have MetS (101). The present study showed that the mean prevalence of MetS in Iran was found to be higher than in many other countries. The reported studies of Asian countries were similar to our findings. The prevalence of the MetS, as reported from several studies in Central in south Asia was 25.9\% (102), Asia-China $33.9 \%$ (103), India $41.6 \%$ (104) and Turkey 36.6\% (104), which showed that its prevalence is relatively high in Asia. Asians have an ethnic predisposition to MetS $(17,105)$, and it is of special concern for Middle Eastern populations (17). Also, the prevalence of MetS in Iran is much closer to that in North Africa $30 \%$ (106) and some Latin American countries such as Colombia 34.8\% (107) and Venezuela 35.3\% (108). The present systematic review indicated that the metabolic syndrome is more prevalent in Iran. Although genetic factors play a significant role in the syndrome, some reasons such as urbanization and inactivity have resulted in this relatively high prevalence of MetS in Iran. Obesity is the major driver of MetS development and sedentary lifestyle, a high-fat and fast food dietary is one of the other risk factors (109). In a nationwide study of the prevalence of the metabolic syndrome in Iran, greater waist circumference values and lower HDL-C have also been reported in Iranian communities than in Western populations, which supports the idea of an ethnic predisposition of the Iranian community to MetS (17). Furthermore, it has been shown that MetS is highly age-dependent (110), our study confirmed this finding. We found that the prevalence of MetS in age groups ( $\geq 18$ years of age) was significantly higher than age groups ( $<18$ years of age) $(31.6 \%$ versus $10.2 \%$, respectively); also it increased around $0.004 \%$ by each year of age increase after the age of 18. In recent years, the population of Iran has been growing older, and this might be one of the reasons for such a high prevalence of MetS in this country. Our findings show that the prevalence of MetS was more prevalent in Iranian women. Evaluation of studies suggests that sex differences in prevalence are more obvious in older ages. This sex difference can be explained by a statistically significant higher prevalence of MetS components in women (Table 3). The lack of consensus on MetS definitions and the cutoff points used for its components, especially regarding waist circumference, has resulted in these differences. In the most commonly used definitions for MetS, the cut-off point for waist circumference is usually higher for men and lower for women, which may have resulted in a higher prevalence of MetS being measured in women. A growing trend with increasing age in both genders was significant. The relatively high prevalence of MetS is a worldwide phenomenon. This prevalence appears to be increasing because of a parallel rise in the prevalence of obesity. The present study found Low HDL-C and hypertriglyceridemia as the most prevalent components of MetS, and could be related to unhealthy dietary patterns and physical inactivity. It was followed by High TG, High WC, High BP and High FBS. Each component of the metabolic syndrome has shown to increase the risk of cardiovascular disease and diabetes separately. Consequently, health professionals could evaluate and treat all metabolic risk factors without regard to whether a patient meets the criteria for diagnosis of the metabolic syndrome.

\section{Limitations:}

There are important clinical and public health implications in our results; the results will further contribute to the public health burden of CVD. There are also several limitations to our meta-analysis as insufficient available data prevented us from conducting separate analyses in the evaluation of all age groups. Other limitation is the lack of information about nutrition and lifestyle of the participants, which could explain part of the observed high prevalence. Furthermore, some studies associated with prevalence of MetS were not accessible. 


\section{Conclusions}

The present study shows that the prevalence of MetS is high in the Iranian adult population. Also, it has a relatively high prevalence among children and adolescents. Metabolic syndrome is more prevalent in women than in men and increases with age in both sexes. The lack of consensus on MetS definitions has resulted in different reports of its prevalence. The most common component of MetS was Low HDL-C which was followed by High TG, High WC, High BP and High FBS. This study shows that MetS is a public health problem in Iran. Therefore, applying an appropriate screening and treatment system for MetS could prevent many chronic diseases that are costly to society.

\section{Acknowledgments:}

The authors extend their gratitude to the Yasuj University of Medical Sciences for its support.

\section{Conflict of Interest:}

There is no conflict of interest to be declared.

\section{Authors' contributions:}

All authors contributed to this project and article equally. All authors read and approved the final manuscript.

\section{References:}

1) Mehrdad SM, Hosseinpanah F, Azizi F. Metabolic syndrome prevalence in 3-9 years old children: Tehran Glucose and Lipid Study. Research in Medicine. 2006; 30(Suppl 4): 337-46.

2) Ghergherehchi R, Razaghi Azar M. Metabolic syndrome prevalence in obese children and adolescents. Medical Journal of Tabriz University of Medical Sciences. 2010; 32(Suppl 3): 57-61.

3) Sadr Bafghi SM, Salari M, Rafiee M, Namayandeh SM, Abdoli AM, Karimi M, et al. Prevalence of metabolic syndrome and its risk factors in an urban population: Yazd Healthy Heart Project. Journal of Tehran University of Medical Sciences. 2006; 64(Suppl 10): 90-6.

4) Fakhrzadeh H, Ebrahimpoor P, Noori M, Poor Ebrahim R, Heshmat R, Shooshtarizadeh P, et al. Prevalence of metabolic syndrome and its risk factors among population under supervision of Population Research Center of Tehran University Of Medical Sciences. Iran Diabetes and Lipid Journal. 2006; 3(Suppl 1): 71-80.

5) Amirkalali B, Fakhrzadeh H, Sharifi F, Kelishadi R, Zamani F, Asayesh H, et al. Prevalence of Metabolic Syndrome and Its Components in the Iranian Adult Population: A Systematic Review and Meta-Analysis. Iran Red Crescent Med J. 2015; 17(Suppl 12): e24723. doi: 10.5812/ircmj.24723. PMID: 26756015.

6) Kaykhaei MA, Hashemi M, Narouie B, Shikhzadeh A, Jahantigh M, Shirzaei E, et al. Prevalence of Metabolic Syndrome in Adult Population from Zahedan, Southeast Iran. Iranian J Publ Health. 2012; 41(2): 70-6. PMID: 23113137, PMCID: PMC3481671.

7) Jover A, Corbella E, Muñoz A, Millán J, Pintó X, Mangas A, et al. Prevalence of metabolic syndrome and its components in patients with acute coronary syndrome. Rev Esp Cardiol. 2011; 64(7): 579-86. doi: 10.1016/j.recesp.2011.03.010. PMID: 21640461.

8) Shin JA, Lee JH, Lim SY, Ha HS, Kwon HS, Park YM, et al. Metabolic syndrome as a predictor of type 2 diabetes, and its clinical interpretations and usefulness. J Diabetes Investig. 2013; 4(4): 334-43. doi: 10.1111/jdi.12075. PMID: 24843675.

9) Sattar N, Gaw A, Scherbakova O, Ford I, O'Reilly DS, Haffner SM, et al. Metabolic syndrome with and without C-reactive protein as a predictor of coronary heart disease and diabetes in the West of Scotland Coronary Prevention Study. Circulation. 2003; 108: 414-9. doi: 10.1161/01.CIR.0000080897.52664.94. PMID: 12860911.

10) Jalali R, Vashaghani M, Dabaghmanesh MH, Ranjbar Omrani GHH. Metabolic syndrome prevalence in adults of Akbar Abad Kovar, Fars Province, in 2008. Iranian Endocrinology and Metabolism Journal. 2009; 11(Suppl 4): 405-14.

11) Santos AC, Ebrahim S, Barros H. Alcohol intake, smoking, sleeping hours, physical activity and the metabolic syndrome. Prev Med. 2007; 44(4): 328-34. doi:10.1016/j.ypmed.2006.11.016. PMID: 17239432.

12) Wilsgaard T, Jacobsen BK. Lifestyle factors and incident metabolic syndrome: the Tromsø Study 19792001. Diabetes Res Clin Pract. 2007; 78(2): 217-24. doi: 10.1016/j.diabres.2007.03.006. PMID: 17448561.

13) Ford ES, Giles WH, Dietz WH. Prevalence of the metabolic syndrome among US adults: findings from the third National Health and Nutrition Examination Survey. JAMA. 2002; 287(3): 356-9. doi: 10.1001/jama.287.3.356. PMID: 11790215.

14) Bender R, Jockel KH, Richter B, Spraul M, Berger M. Body weight, blood pressure, and mortality in a cohort of obese patients. Am J Epidemiol. 2002; 156(3): 239-45. doi: 10.1093/aje/kwf015. PMID: 12142258 . 
15) Kazemi S, Koosha A, Sharifi F, Moosavi-Nasab SND, Mellati AA: Metabolic syndrome prevalence in 1721 years old population of Zanjan: a new definition for waist circumference in Iranians in comparison with ATPIII and World Diabetes Association. Iran Diabetes and Lipid Journal. 2008; 7(Suppl 4): 393-8.

16) Azizi F, Salehi P, Etemadi A, Zahedi-Asl S. Prevalence of metabolic syndrome in an urban population: Tehran lipid and glucose study. Diabetes Res Clin Pract. 2003; 61(1): 29-37. doi: 10.1016/S01688227(03)00066-4.

17) Delavari A, Forouzanfar MH, Alikhani S, Sharifian A, Kelishadi R. First nationwide study of the prevalence of the metabolic syndrome and optimal cutoff points of waist circumference in the Middle East: the national survey of risk factors for noncommunicable diseases of Iran. Diabetes Care. 2009; 32(6): 1092-7. doi: 10.2337/dc08-1800. PMID: 19279302, PMCID: PMC2681035.

18) Noori N, Mirmiran P, Asgari S, Azizi F. Calcium and vitamin D intake and metabolic syndrome prevalence in Tehranian adults: Tehran Glucose and Lipid Study. Iranian Endocrinology and Metabolism Journal. 2007; 9(Suppl 1): 191-200.

19) Pyorala K. Assessment of coronary heart disease risk in populations with different levels of risk. Eur Heart J. 2000; 21(5): 348-50. doi: 10.1053/euhj.1999.1927. PMID: 10666347.

20) von Elm E, Altman DG, Egger M, Pocock SJ, Gotzsche PC, Vandenbroucke JP, et al. The Strengthening the Reporting of Observational Studies in Epidemiology [STROBE] statement: guidelines for reporting observational studies. Gac Sanit. 2008; 22(2): 144- 50. doi: 10.1157/13119325. PMID: 18420014.

21) Ebrahimpoor P, Fakhrzadeh H, Rasoolpoor E, Hamidi A, Heshamat R, Noori M, et al. Metabolic syndrome and its association with insulin level in obese children of primary schools of Tehran. Journal of Iran University of Medical Sciences. 2006; 13(Suppl 51): 7-15.

22) Esmaillzadeh A, Mirmiran P, Azadbakht L, Etemadi A, Azizi F. High prevalence of the metabolic syndrome in Iranian adolescents. Obesity 2006; 14(Suppl 3): 377-82. doi: 10.1038/oby.2006.50. PMID: 16648607.

23) Sadeghi M, Roohafza HR, Shirani Sh, Baghaee AM, Golshadi I, Aghdak P. Assessment and relationship between hematologic and metabolic syndrome parameters in Iranian population: Isfahan Healthy Heart Study. Journal of Rafsanjan University of Medical Sciences. 2006; 5(Suppl 2): 57-61.

24) Malek M, Hadaegh F, Harati H, Azizi F. Predict cardiovascular events in people over 40 years of age with metabolic syndrome according to ATP III and IDF definitions (Tehran Lipid and Glucose Study). Journal of Endocrinology and Metabolism. 2006; 8(3): 249-57.

25) Gharipour M, Baghei A, Boshtam M, Rabiei K. Prevalence of metabolic syndrome among the adults of central of areas of Iran (as part of Isfahan Healthy Heart Study). Journal of Birjand University of Medical Sciences. 2006; 13(3): 56- 63.

26) Zabetian A, Hadaegh F, Tohidi M, Sheikholeslami F, Azizi F. Metabolic syndrome prevalence in middleage population based on WHO, IDF, and ATPIII criteria and its relationship with coronary heart diseases. Iran Diabetes and Lipid Journal. 2007; 7(Suppl 1): 91-101.

27) Nabipoor I, Amiri M, Imami SR, Jafari SM, Shafeiae E, Nosrati A, et al. The metabolic syndrome and nonfatal ischemic heart disease; a population-based study. International Journal of Cardiology 2007; 118: 48-53. doi: 10.1016/j.ijcard.2006.06.017. PMID: 16875744.

28) Salem Z, Vazirinezhad R. Prevalence of metabolic syndrome among 18 year old girls in Rafsanjan, 2007. Iran Diabetes and Lipid Journal. 2008; 7(2): 205-13.

29) Hadegh F, Ghasemi A, Padyab M, Tohidi M, Azizi F. The metabolic syndrome and incident diabetes: Assessment of alternative definitions of the metabolic syndrome in an Iranian urban population. Diabetes Research and Clinical Practice. 2008; 80: 328-34. doi: 10.1016/j.diabres.2008.01.003. PMID: 18282630.

30) Kelishadi R, Gouya MM, Adeli KH, Ardalan G, Gheiratmand R, Majdzadeh R, et al. Factors associated with the metabolic syndrome in a national sample of youths: CASPIAN Study. Nutrition, Metabolism \& Cardiovascular Diseases. 2008; 18: 461-70. doi: 10.1016/j.numecd.2007.02.014. PMID: 17935959.

31) Sarrafzadegan N, Kelishadi R, Baghaei A, Hussein Sadri G, Malekafzali H, Mohammadifard N, et al. Metabolic syndrome: an emerging public health problem in Iranian women: Isfahan Healthy Heart Program. Int J Cardiol. 2008; 131(1): 90-6. doi: 10.1016/j.ijcard.2007.10.049. PMID: 18190978.

32) Mirhosseini NZ, Noor- Aini MY, Shahar S, Parizadeh SMR, Mobarhen MG, Shakery MT. Prevalence of the metabolic syndrome and its influencing factors among adolescent girls in Mashhad, Iran. Asia Pac J Clin Nutr. 2009; 18(Suppl 1): 131-6. PMID: 19329406.

33) Delavar MA, Lye MS, Khor GL, Hanachi P, Hassan ST. Prevalence of metabolic syndrome among middle aged women in Babol, Iran. Southeast Asian J Trop Med Public Health. 2009; 40(3): 612-28. PMID: 19842450 . 
34) Barahimi H, Rajaie F, Esmaielian R. Prevalence of metabolic syndrome in women of reproductive age in Shahreza, 2007. Iran Diabetes and Lipid Journal. 2009; 8(2): 177-84.

35) Saberi HR, Parastooie K, Maroji SA. Metabolic syndrome in bus and truck drivers in Kashan. Iranian South Medical Journal. 2009; 12(2): 126-32.

36) Sharifi F, Mousavinasab SN, Saeini M, Dinmohammadi M. Prevalence of metabolic syndrome in an adult urban population of the west of Iran. Exp Diabetes Res. 2009; 2009: 136501. doi: 10.1155/2009/136501. PMID: 19893638.

37) Chiti H, Hosseinpanah F, Mehrabi Y, Azizi F. The Prevalence of Metabolic Syndrome in Adolescents with Varying Degrees of Body Weight: Tehran Lipid and Glucose Study (TLGS). Iranian Journal of Endocrinology \& Metabolism. 2010; 11(6): 625-730.

38) Ghasemi A, Zahediasl S, Syedmoradi L, Azizi F. Low serum magnesium levels in elderly subjects with metabolic syndrome. Biol Trace Elem Res. 2010; 136(1): 18-25. doi: 10.1007/s12011-009-8522-7. PMID: 19763407.

39) Esmaillzadeh A, Azadbakht L. Dietary energy density and the metabolic syndrome among Iranian women. Eur J Clin Nutr. 2011; 65(5): 598-605. doi: 10.1038/ejen.2010.284. PMID: 21224871.

40) Esteghamati A, Noshad S, Khalilzadeh O, Morteza A, Nazeri A, Meysamie A, et al. Contribution of serum leptin to metabolic syndrome in obese and nonobese subjects. Arch Med Res. 2011; 42(3): 244-51. doi: 10.1016/j.arcmed.2011.05.005. PMID: 21722822.

41) Mehrkesh M, Mohammadian S, Ghorbani M, Eshghinia S, Shafa N. Prevalency of metabolic syndrome among adolescents aged 15 to 17 years in Gorgan, Northern Iran (2009). Journal of Gorgan University of Medical Sciences. 2011; 13(Suppl 2): 93-9.

42) Noshad N, Abbasi M, Etemad A, Afarideh M, Khajeh E, Asgari F, et al. The Prevalence of Metabolic Syndrome in Iran: a 2011 Update. J Diabetes. 2016: 34(5): 1243-8. doi: 10.1111/1753-0407.12438. PMID: 27262869.

43) Ebrahimi Mamghani M, Farsad Naeimi AR, Noor Mohamadi M, Ozbodftari N. Prevalence of metabolic syndrome in firefighters Tabriz. Bhbood. 2011; 15(4): 296-302.

44) Rahmanian K, Shojaie M. Prevalence of Metabolic Syndrome in an Adult Urban Population in The South of Iran. Iranian Journal of Diabetes and Obesity. 2011; 3(2): 77-82.

45) Ramezani Tehrani F, Tohidi M, Rostami M, Asgari S, Azizi F. The association between sub-clinical hypothyroidism and metabolic syndrome: A population based study. Iran J Endocrinol Metab. 2011; 13(1): 98-105.

46) Hadaegh F, Zabetian A, Khalili D, Safarkhani M, James WPT, Azizi F. A new approach to compare the predictive power of metabolic syndrome defined by a joint interim statement versus its components for incident cardiovascular disease in Middle East Caucasian residents in Tehran. J Epidemiol Community Health. 2012; 66(5): 427-32. doi: 10.1136/jech.2010.117697. PMID: 21051780.

47) Ghorbani R, Naeini BA, Eskandarian R, Rashidy-Pour A, Khamseh ME, Malek M. Prevalence of metabolic syndrome according to ATPIII and IDF criteria in the Iranian population. Koomesh. 2012; 14(1): $65-75$.

48) Marjani M, Moghasemi S. The Metabolic Syndrome among Postmenopausal Women in Gorgan. Int J Endocrinol. 2012; 2012: 953627. doi: 10.1155/2012/953627. PMID: 22518135, PMCID: PMC3296160.

49) Mahjoub S, Haji Ahmadi M, Faramarzi M, Ghorbani H, Moazezi Z. The prevalence of metabolic syndrome according to the Iranian Committee of Obesity and ATP III criteria in Babol, North of Iran. Caspian J Intern Med. 2012; 3(2): 410-6. PMID: 24358435, PMCID: PMC3861904.

50) Yousefzadeh G, Shokoohi M, Yeganeh M, Najafipour H. Role of gamma-glutamyl transferase (GGT) in diagnosis of impaired glucose tolerance and metabolic syndrome: a prospective cohort research from the Kerman Coronary Artery Disease Risk Study (KERCADRS). Diabetes Metab Syndr. 2012; 6(4): 190-4. doi: 10.1016/j.dsx.2012.08.013. PMID: 23199536.

51) Mohebbi I, Saadat S, Aghassi M, Shekari M, Matinkhah M, et al. Prevalence of Metabolic Syndrome in Iranian Professional Drivers: Results from a Population Based Study of 12,138 Men. PLoS One. 2012; 7(2): e31790. doi:10.1371/journal.pone.0031790. PMID: 22384075.

52) Yazdi Z, Sarreshtedari M, Taiefi MH. Prevalence of metabolic syndrome and its associated factors among drivers of heavy vehicles. Journal of Birjand University of Medical Sciences. 2012; 5(4): 68-72.

53) Rezaianzadeh A, Namayandeh SM, Sadr SM. National cholesterol education program adult treatment panel III versus international diabetic federation definition of metabolic syndrome, which one is associated with diabetes mellitus and coronary artery disease? Int J Prev Med. 2012; 3: 552-8. PMID: 22973485, PMCID: PMC3429802. 
54) Zarkesh M, Faam B, Daneshpour MS, Azizi F, Hedayati M. The relationship between metabolic syndrome, cardiometabolic risk factors and inflammatory markers in a tehranian population: The tehran lipid and glucose study. Inte Med. 2012; 51(24): 3329-35. doi: 10.2169/internalmedicine.51.8475.

55) Talaei M, Thomas GN, Marshall T, Sadeghi M, Iranipour R, Oveisgharan S, et al. Appropriate cut-off values of waist circumference to predict cardiovascular outcomes: 7-year follow-up in an iranian population. Int Med. 2012; 51(2): 139-46. doi: 10.2169/internalmedicine.51.6132.

56) Azimi-Nezhad M, Herbeth B, Siest G, Dade S, Ndiaye NC, Esmaily H, et al. High prevalence of metabolic syndrome in Iran in comparison with France: what are the components that explain this? Metab Syndr Relat Disord. 2012; 10(3): 181-8. doi: 10.1089/met.2011.0097. PMID: 22283632.

57) Movahed A, Larijani B, Nabipour I, Kalantarhormozi M, Asadipooya K, Vahdat K, et al. Reduced serum osteocalcin concentrations are associated with type 2 diabetes mellitus and the metabolic syndrome components in postmenopausal women: the crosstalk between bone and energy metabolism. J Bone Miner Metab. 2012; 30(6): 683-91. doi: 10.1007/s00774-012-0367-z. PMID: 22752126.

58) Shahbazian H, Latifi SM, Jalali MT, Shahbazian H, Amani R, Nikhoo A, et al. Metabolic syndrome and its correlated factors in an urban population in South West of Iran. Journal of Diabetes \& Metabolic Disorders. 2013; 12: 11. doi: 10.1186/2251-6581-12-11. PMID: 23497506.

59) Gholipour M, Tabrizi A, Kazem Neshad A. Prevalence of metabolic syndrome in students and its relationship with obesity markers. Iran Diabetes and Lipid Journal. 2013; 12(4): 324-34.

60) Ahmadi A, Gharipour M, Nouri F, Sarrafzadegan N. Metabolic Syndrome in Iranian Youths: A PopulationBased Study on Junior and High Schools in Rural and Urban Areas. J Diabetes Res. 2013; 2013: 738485. doi: 10.1155/2013/738485. PMID: 23819128.

61) Shahini N, Shahin I, Marjani A. The Metabolic Syndrome among Turkmen Ethnic Groups in Gorgan, Iran. Journal of Clinical and Diagnostic Research. 2013; 7(9): 1849-51. doi: 10.7860/JCDR/2013/6035.3331. PMID: 24179879.

62) Maharlouei N, Bellissimo N, Ahmadi SM, Lankarani KB. Prevalence of metabolic syndrome in pre- and postmenopausal Iranian women. Climacteric. 2013; 16: 561-7. doi: 10.3109/13697137.2012.727504. PMID: 23157491.

63) Faam B, Hosseinpanah F, Amouzegar A, Ghanbarian A, Asghari G, Azizi F. Leisure-time physical activity and its association with metabolic risk factors in Iranian adults: Tehran Lipid and Glucose Study, 20052008. Prev Chronic Dis. 2013; 10: 36. doi: 10.5888/ pcd10.120194. PMID: 23489641.

64) Ziaee A, Esmailzadehha N, Ghorbani A, Asefzadeh S. Association between Uric Acid and Metabolic Syndrome in Qazvin Metabolic Diseases Study (QMDS), Iran. Glob J Health Sci. 2013; 5(1): 155-65. doi: 10.5539/gjhs.v5n1p155. PMID: 23283048.

65) Ostovaneh MR, Zamani F, Sharafkhah M, Ansari-Moghaddam A, Akhavan Khaleghi N, Saeedian FS, et al. Prevalence of metabolic syndrome in Amol and Zahedan, Iran: A population based study. Arch Iran Med. 2014; 17(7): 477-82. doi: 0141707/AIM.006. PMID: 24979559.

66) Javadi HR, Hashemipour S, Abbasi M, Javadi A. Prevalence of metabolic syndrome and its components in over 24 years old population of Qazvin (2012). JQUMS. 2014; 18(3): 11-7.

67) Rashidi H, Payami SP, Latifi SM, Karandish M, Moravej Aleali A, Aminzadeh M, et al. Prevalence of metabolic syndrome and its correlated factors among children and adolescents of Ahvaz aged 10-19. Journal of Diabetes \& Metabolic Disorders. 2014; 13: 53. doi: 10.1186/2251-6581-13-53. PMID: 24860794.

68) Amiri P, Deihim T, Hosseinpanah F, Barzin M, Hasheminia M, Montazeri A, et al. Research: Educational and Psychological Issues Diagnostic values of different definitions of metabolic syndrome to detect poor health status in Iranian adults without diabetes. Diabet Med. 2014; 31: 854-61. doi: 10.1111/dme.12443.

69) Gozashti MH, Fedaei N, Shojaei M, Najafipour H. Determination of most suitable cut off point of waist circumference for diagnosis of metabolic syndrome in Kerman. Diabetes Metab Syndr. 2014; 8: 8-12. doi: 10.1016/j.dsx.2013.10.022. PMID: 24661751.

70) Hosseinpanah F, Salehpour M, Asghari G, Barzin M, Mirmiran P, Hatami H, et al. Adolescent metabolic phenotypes and early adult metabolic syndrome: Tehran lipid and glucose study. Diabetes Research and Clinical Practice. 2015; 109: 287-92. doi: 10.1016/j.diabres.2015.05.022. PMID: 26026779.

71) Tabatabaie AH, Shafiekhani M, Nasihatkon AA, Hafizi Rastani I, Tabatabaie M, Borzoo AR, et al. Prevalence of metabolic syndrome in adult population in Shiraz, southern Iran. Diabetes Metab Syndr. 2015; 9: 153-6. doi: 10.1016/j.dsx.2015.04.012. PMID: 25952039.

72) Alavi SS, Makarem J, Mehrdad R, Abbasi M. Metabolic syndrome: A common problem among office workers. Int J Occup Environ Med. 2015; 6: 34-40. doi: 10.15171/ijoem.2015.492. PMID: 25588224. 
73) Azak S, Mohebbi M, Salarilak Sh, Gharaaghaji Asl R. Prevalence of metabolic syndrome and related risk factors in professional drivers in West Azerbaijan, 2010- 2012. The Journal of Urmia University of Medical Sciences. 2015; 26(9): 775-84.

74) Moradi M, Rafiei E, Ebrahim Zadeh F, Baba H, Balaro S, Ali Mohammadi M. The prevalence of metabolic syndrome among students of Lorestan University of Medical Sciences. Medical Journal of Mashhad, University of Medical Sciences. 2015; 57(8): 918- 25.

75) Zardast M, Namakin K, Chahkandi T, Taheri F, Kazemi T, Bijari B. Prevalence of metabolic syndrome in elementary school children in East of Iran. J Cardiovasc Thorac Res. 2015; 7(4): 158-63. doi: 10.15171/jcvtr.2015.34. PMID: 26702345.

76) Mohammadi Sh, Mirmiran P, Bahadoran Z, Mehrabi Y, Azizi F. The Association of Dairy Intake with Metabolic Syndrome and Its Components in Adolescents: Tehran Lipid and Glucose Study. Int J Endocrinol Metab. 2015; 13(3): e25201. doi: 10.5812/ijem.25201v2. PMID: 26425126.

77) Namazi Shabestari A, Asadi M, Jouyandeh Z, Qorbani M, Kelishadi R. Association of Lipid Accumulation Product with Cardio-Metabolic Risk Factors in Postmenopausal Women. Acta Med Iran. 2016; 54(6): 3705. PMID: 27306343.

78) Yousefzadeh Gh, Shokoohi M, Najafipour H, Shadkamfarokhi M. Applying the Framingham risk score for prediction of metabolic syndrome: The Kerman Coronary Artery Disease Risk Study, Iran. ARYA Atheroscler. 2015; 11(3): 179-85. PMID: 26405450

79) Mousavi A, biglariA, Reyhanian M. Prevalence of Metabolic Syndrome and Its Related Criteria in Health Network Personnel in Babolsar, 2012. J Mazandaran Univ Med Sci. 2015; 25(122): 379-83.

80) Ebrahimi H, Emamian MH, Shariati M, Hashemi H, Fotouhi A. Metabolic syndrome and its risk factors among middle aged population of Iran, a population based study. Diabetes Metab Syndr. 2016; 10: 19-22. doi: 10.1016/j.dsx.2015.08.009. PMID: 26341930

81) Ebrahimi MH, Delvarianzadeh M, Saadat S. Prevalence of metabolic syndrome among Iranian occupational drivers. Diabetes Metab Syndr. 2016; 10: 46-51. doi: 10.1016/j.dsx.2015.09.011.

82) Baygi FC, Jensen O, Qorbani M, Farshad A, Salehi SA, Mohammadi-Nasrabadi F, et al. Prevalence and associated factors of cardio-metabolic risk factors in Iranian seafarers. Int Marit Health. 2016; 67(2): 5965. doi: 10.5603/IMH.2016.0013. PMID: 27364169.

83) Ahrens W, Moreno LA, Mårild S, Molnár D, Siani A, De Henauw S, et al. Metabolic syndrome in young children: definitions and results of the IDEFICS study. Int J Obes. 2014; 38(Suppl 2): S4-14. doi: 10.1038/ijo.2014.130 I. PMID: 25376220.

84) De Ferranti SD, Osganian SK. Epidemiology of paediatric metabolic syndrome and type 2 diabetes mellitus. Diab Vasc Dis Res. 2007; 4(4): 285-96. doi: 10.3132/dvdr.2007.055. PMID: 18158698.

85) Rosini N, Moura SA, Rosini RD, Machado MJ, Silva EL. Metabolic Syndrome and Importance of Associated Variables in Children and Adolescents in Guabiruba - SC, Brazil. Arq Bras Cardiol. 2015; 105(1): 37-44. doi: 10.5935/abc.20150040. PMID: 25993484.

86) Rodriguez Moran M, Salazar-Vazquez B, Violante R, Guerrero-Romero F. Metabolic syndrome among children and adolescents aged 10-18-years. Diabetes Care. 2004; 27(10): 2516-7. doi: 10.2337/diacare.27.10.2516. PMID: 15451932.

87) Inanc BB. Metabolic Syndrome in School Children in Mardin, South-Eastern of Turkey. Eurasian J Med 2014; 46(3): 156-63. doi: 10.5152/eajm.2014.39. PMID: 25610318.

88) Harabbi I, Bouaouina M, Maatoug J, Gaha R, Ghannem H. Prevalence of the metabolic syndrome among urban schoolchildren in Sousse, Tunisia. Int J Cardiol. 2009; 135(1): 130-1. doi: 10.1016/j.ijcard.2008.01.035. PMID: 18495275.

89) Liu W, Lin R, Liu A, Du L, Chen Q. Prevalence and association between obesity and metabolic syndrome among Chinese elementary school children: a school-based survey. BMC Public Health. 2010; $10: 780$. doi: 10.1186/1471-2458-10-780. PMID: 21176200.

90) Singh R, Bhansali A, Sialy R, Aggarwal A. Prevalence of metabolic syndrome in adolescents from a north Indian population. Diabet Med. 2007; 24(2): 195-9. doi:10.1111/j.1464-5491.2007.02066.x. PMID: 17257283.

91) Iqbal AZ, Basharat S, Basharat A, Basharat S. Prevalence of the metabolic syndrome and its component abnormalities among school age Pakistani children. J Ayub Med Coll Abbottabad. 2014; 26(2): 194-9. PMID: 25603676.

92) Zardast M, Namakin K, Chahkandi T, Taheri F, Kazemi T, Bijari B. Prevalence of Metabolic Syndrome in Elementary School Children in East of Iran. J Cardiovasc Thorac Res. 2015; 7(4): 158-63. doi: 10.15171/jcvtr.2015.34. PMID: 26702345. 
93) Conceicao-Machado ME, Silva LR, Santana ML, Pinto EJ, Silva Rde C, Moraes LT, et al. Hypertriglyceridemic waist phenotype: association with metabolic abnormalities in adolescents. J Pediatr. 2013; 89: 56-63. doi: 10.1016/j.jped.2013.02.009. PMID: 23544811.

94) International diabetes federation $\quad$ Icwadotms. $\quad$ Available from: http://www.idf.org/webdata/docs/IDF_Meta_def_final.pdf.

95) Boonyavarakul A, Choosaeng C, Supasyndh O, Panichkul S. Prevalence of the metabolic syndrome, and its association factors between percentage body fat and body mass index in rural Thai population aged 35 years and older. J Med Assoc Thai. 2005; 88(Suppl 3): 121-30. PMID: 16858950.

96) Corbaton-Anchuelo A, Martinez-Larrad MT, Fernandez-Perez C, Vega-Quiroga S, Ibarra-Rueda JM, Serrano-Rios M, et al. Metabolic syndrome, adiponectin, and cardiovascular risk in Spain (the Segovia study): impact of consensus societies criteria. Metab Syndr Relat Disord. 2013; 11(5): 309-18. doi: 10.1089/met.2012.0115. PMID: 23734759.

97) Giampaoli S, Stamler J, Donfrancesco C, Panico S, Vanuzzo D, Cesana G, et al. The metabolic syndrome: a critical appraisal based on the CUORE epidemiologic study. Prev Med. 2009; 48(6): 525-31. doi: 10.1016/j.ypmed.2009.03.017. PMID: 19344739.

98) Fonseca MJ, Gaio R, Lopes C, Santos AC. Association between dietary patterns and metabolic syndrome in a sample of Portuguese adults. Nutr J. 2012; 11: 64. doi: 10.1186/1475-2891-11-64. PMID: 22943133.

99) Wagner A, Dallongeville J, Haas B, Ruidavets JB, Amouyel P, Ferrieres J, et al. Sedentary behaviour, physical activity and dietary patterns are independently associated with the metabolic syndrome. Diabetes Metab. 2012; 38(5): 428-35. doi: 10.1016/j.diabet.2012.04.005. PMID: 22721723.

100) Beltran-Sanchez H, Harhay MO, Harhay MM, McElligott S. Prevalence and trends of metabolic syndrome in the adult U.S. population, 1999-2010. J Am Coll Cardiol. 2013; 62(8): 697-703. doi: 10.1016/j.jacc.2013.05.064. PMID: 23810877.

101) Grundy SM. Metabolic syndrome pandemic. Arterioscler Thromb Vasc Biol. 2008; 28(4): 629-36. doi: 10.1161/ATVBAHA.107.151092. PMID: 18174459.

102) Lohsoonthorn V, Dhanamun B, Williams MA. Prevalence of metabolic syndrome and its relationship to white blood cell count in a population of Thai men and women receiving routine health examinations. Am J Hypertens. 2006; 19: 339-45. doi: 10.1016/j.amjhyper.2005.10.008. PMID: 16580566.

103) Wang GR, Li L, Pan YH, Tian GD, Lin WL, Li Z, et al. Prevalence of metabolic syndrome among urban community residents in China. BMC Public Health. 2013; 13: 599. doi: 10.1186/1471-2458-13-599. PMID: 23786855.

104) Kim MH, Kim MK, Choi BY, Shin YJ. Prevalence of metabolic syndrome and its association with cardiovascular disease in korea. J Korean Med Sci. 2004; 19: 195-201. doi: 10.3346/jkms.2004.19.2.195. PMID: 15082890 .

105) Kelishadi R, Ardalan G, Gheiratmand R, Adeli K, Delavari A, Majdzadeh R, et al. Paediatric metabolic syndrome and associated anthropometric indices: the CASPIAN Study. Acta Paediatr. 2006; 95(12): 1625-34. doi: 10.1080/08035250600750072. PMID: 17129973.

106) Belfki H, Ben Ali S, Aounallah-Skhiri H, Traissac P, Bougatef S, Maire B, et al. Prevalence and determinants of the metabolic syndrome among Tunisian adults: results of the Transition and Health Impact in North Africa (TAHINA) project. Public Health Nutr. 2013; 16(4): 582-90. doi: 10.1017/S1368980012003291. PMID: 22883486.

107) Pinzon JB, Serrano NC, Diaz LA, Mantilla G, Velasco HM, Martinez LX, et al. Impact of the new definitions in the prevalence of the metabolic syndrome in an adult population at Bucaramanga, Colombia. Biomedica. 2007; 27(2): 172-9. doi: /S0120-41572007000800004. PMID: 17713628.

108) Florez H, Silva E, Fernandez V, Ryder E, Sulbaran T, Campos G, et al. Prevalence and risk factors associated with the metabolic syndrome and dyslipidemia in White, Black, Amerindian and Mixed Hispanics in Zulia State, Venezuela. Diabetes Res Clin Pract. 2005; 69(1): 63-77. doi: 10.1016/j.diabres.2004.11.018. PMID: 15955388.

109) Ford ES, Giles WH, Dietz WH. Prevalence of the Metabolic Syndrome Among US Adults. JAMA. 2002; 287(Suppl 3): 356-9. PMID: 11790215.

110) Park YW, Zhu S, Palaniappan L, Heshka S, Carnethon MR, Heymsfield SB. The metabolic syndrome: prevalence and associated risk factor findings in the US population from the Third National Health and Nutrition Examination Survey, 1988-1994. Arch Intern Med. 2003; 163(4): 427-36. doi: 10.1001/archinte.163.4.427. PMID: 12588201, PMCID: PMC3146257. 